\author{
JURNAL TEKNOLOGI LABORATORIUM \\ (www.teknolabjournal.com) \\ Vol.6, No.1, Maret 2017, pp. $31 \sim 38$ \\ ISSN: 2338 - 5634 (print); ISSN: 2580-0191 (online)
}

\title{
Kajian Aktivitas Antikanker Ekstrak Daun Gude (cajanus cajan) Terhadap Sel Kanker Kolon Secara in Vitro
}

\author{
Muji Rahayu ${ }^{{ }^{*}}$, Roosmarinto ${ }^{2}$ \\ 1,2 Jurusan Analis Kesehatan Poltekkes Kemenkes Yogyakarta \\ Jln. Ngadinegaran MJ III/62 Yogyakarta \\ "Corresponding author email: hayuningpuji@gmail.com
}

\begin{abstract}
Colorectal cancer is one of the five type of highest insiden in Indonesia. One of development cancer therapeutics directed to combination of chemotherapeutic agent and chemopreventive compounds. One approach to finding a chemopreventive compounds is through the exploration of natural ingredient especialy herbs. Flavonoids is group of compounds from plants that have been widely studied as anti-cancer activity. Leave of pigeonpea (Cajanus cajan) is, kind of Legumes plants rich in flavonoids among others cajanol, quercetin, luteolin, apigenin formonentin, vitexin, orientin, biochanin A, pinostrobin, dan isorhamnetin. This study aims to determine the content of chemical compounds in the methanol extract of leave pigeon pea that has anticancer activity using WiDr colorectal cancer cells with MTT (3-(4, 5dimethylthiazolyl-2)-2, 5-diphenyltetrazolium bromide) method, followed by flowcytometry test. The result of the cytotoxicity test of methanol extract of pigeonpea leaves have $\mathrm{IC}_{50}$ of $307 \mathrm{ug} / \mathrm{ml}$ and with flowcytometry method showed necrosis WiDr cell.
\end{abstract}

Keywords: anticancer; pigeonpea leaves; WiDr cells; MTT

(C) 2017 Jurnal Teknologi Laboratorium

\begin{abstract}
Abstrak
Kanker kolorektal merupakan salah satu dari lima jenis kanker yang terbanyak di Indonesia. Salah satu pengembangan terapi kanker diarahkan pada terapi kombinasi antara suatu agen kemoterapi dengan senyawa kemopreventif. Salah satu pendekatan untuk menemukan senyawa kemopreventif adalah melalui eksplorasi bahan alam terutama tumbuhtumbuhan. Flavonoid merupakan sekelompok senyawa dari tanaman yang telah banyak diteliti aktivitasnya sebagai antikanker. Daun gude adalah salah satu tanaman Legume yang kaya akan flavonoid antara lain, cajanol, quercetin, luteolin, apigenin formonentin, vitexin, orientin, biochanin A, pinostrobin, dan isorhamnetin. Tujuan penelitian ini adalah untuk mengetahui adanya aktivitas antikanker ekstrak metanol daun gude. Ekstrak methanol diperoleh dengan etode maserasi. Penelitian ini menggunakan sel kanker kolorektal WiDr, dengan metode MTT dilanjutkan dengan uji flowcytometry.

Hasil uji sitotoksisitas didapatkan $\mathrm{IC}_{50}$ ekstrak methanol daun gude sebesar $307 \mu \mathrm{g} / \mathrm{mL}$. Hasil flowcytometry menunjukkan kematian sel WiDr terjadi secara nekrosis.
\end{abstract}

Kata kunci: antikanker; daun gude (Cajanus cajan); sel WiDr; MTT 


\section{JURNAL TEKNOLOGI LABORATORIUM}

(www.teknolabjournal.com)

Vol.6, No.1, Maret 2017, pp. $31 \sim 38$

ISSN: 2338 - 5634 (print); ISSN: 2580-0191 (online)

Received : 23-03-2017; Revised : 25-04-2017 ; Accepted : 23-05-2017

\section{Pendahuluan}

Flavonoid merupakan sekelompok senyawa dari tanaman yang telah banyak diteliti aktivitasnya sebagai antikanker. Screening pengaruh flavonoid terhadap proliferasi sel dan potensi sitotoksisitas telah dilakukan pada lebih dari 30 senyawa terhadap sel kanker kolon jenis Caco-2 dan HT-29. Hampir semua senyawa menunjukkan aktivitas antiproliferatif tanpa efek sitotoksisitas. Hubungan antara struktur kimia dengan aktivitas antiproliferatif (SAR= structure-activity relationship) juga telah dibuktikan berdasar subkelas flavonoid yaitu isoflavon, flavon, flavonol, dan flavonon.[1] Hampir 1,4 juta kasus baru didiagnosis pada tahun 2012, tingkat kematian 50\%, dengan sebaran $54 \%$ di negara maju, tertinggi di Eropa dan terendah di Asia dan Afrika.[2] Kacang polong-polongan (Legume) merupakan tanaman yang kaya kandungan senyawa flavonoid. Kacang gude adalah satu jenis kacang-kacangan yang mengandung berbagai senyawa polifenol, antara lain antosianin, dan flavonoid. [3] Flavonoid pada tanaman gude meliputi sub kelas flavon, isoflavon, isoflavanon, flavanon, flavonol, antocyanidin, dan chalcon.[4] Kandungan senyawa flavonoid pada daun gude lebih tinggi daripada bijinya.[5]

\section{Metode Penelitian}

\subsection{Bahan}

Daun gude diperoleh dari desa Girimulyo, Gunungkidul

Phosphat buffer aline (PBS), Tripsin-EDTA, Media kultur (MK) (RPMI), dimethylsufoxide (DMSO), MTT (3-(4, 5-dimethylthiazolyl-2)-2, 5-diphenyltetrazolium bromide) $5 \mathrm{mg} / \mathrm{mL}$ Phosphat Buffer Saline (PBS) (50 mg MTT dan $10 \mathrm{~mL}$ PBS), SDS $10 \%$ dalam $0,01 \mathrm{~N} \mathrm{HCl}$, Tripsin-EDTA 0,25\%, RNase, reagen kit Anexin $\mathrm{V}$ (Bio Legend), kultur sel WiDr diperoleh dari koleksi laboratorium Parasitologi Fakultas Kedokteran UGM Yogyakarta.

\subsection{Pembuatan Ekstrak Metanol Daun Gude}

Daun Cajanus cajan yang dikeringkan di udara $(100 \mathrm{~g})$ dihaluskan, dicampur dengan $70 \%$ metanol (metanol dan air dengan perbandingan $70: 30$ ) sebanyak 500 $\mathrm{mL}$ dan dimasukkan dalam shaker semalam (12 jam, $37^{\circ} \mathrm{C}, 160 \mathrm{rpm}$ ). Campuran disentrifugasi pada $2850 \mathrm{~g}$ selama 20 menit. Supernatan dikumpulkan dan endapan dicampur dengan $500 \mathrm{~mL} 70 \%$ methanol dan diekstraksi ulang. Supernatan dikumpulkan dari kedua fase dicampur dan disaring. Filtrat dipekatkan dalam rotary evaporator di bawah tekanan rendah. Ekstrak pekat diliofilisasi dan disimpan pada suhu $-20{ }^{\circ} \mathrm{C}$ sampai digunakan lebih lanjut. Penetapan Kadar Flavonoid Total dilakukan di LPPT UGM Yogyakarta dengan metode spektrofotometri.

Penelitian dilakukan pada bulan April sampai September 2016. Rancangan penelitian ini post test with control group design. Pengujian Sitotoksisitas dengan metode MTT, dilakukan di laboratorium Parasitologi Fakultas Kedokteran UGM Yogyakarta. Flowcytometry dilakukan di laboratorium Patologi Klinik Fakultas Kedokteran UGM Yogyakarta dengan pereaksi Annexin V.

Uji aktivitas antikanker secara uji sitotoksik dengan metode MTT menggunakan sel kanker WiDr dengan variasi konsentrasi ekstrak methanol daun gude: 500, 400, 300, 200 dan $100 \mu \mathrm{g} / \mathrm{ml}$. Sebagai pembanding digunakan 5 Fluorouracil (5-FU), dengan variasi konsentrasi yang sama. 


\section{JURNAL TEKNOLOGI LABORATORIUM}

(www.teknolabjournal.com)

Vol.6, No.1, Maret 2017, pp. $31 \sim 38$

ISSN: 2338 - 5634 (print); ISSN: 2580-0191 (online)

\section{Hasil Dan Pembahasan}

Kadar flavonoid total ekstrak metanol daun gude (Cajanus cajan) ditetapkan dengan metode spektrofotometri, dihitung sebagai eqivalen quercetin dalam penelitian ini ditemukan sebesar 1,84\% (1840 mg/100 gram), angka ini jauh lebih besar bila dibandingkan penelitian yang telah dilakukan oleh Aja dkk (2015) yaitu sebesar $423,75 \mathrm{mg} / 100$ gram.[5] Dari hasil pengujian sitotoksisitas diperoleh $\mathrm{IC}_{50}$ masingmasing $307 \mu \mathrm{g} / \mathrm{ml}$ dan $708 \mu \mathrm{g} / \mathrm{ml}$.

Tabel 1. Persentase Sel WiDr Hidup setelah Perlakuan dengan Ekstrak Metanol Daun Gude

\begin{tabular}{ccc}
\hline Konsentrasi & \multicolumn{2}{c}{ \% sel hidup } \\
\hline & $\begin{array}{c}\text { Ekstrak Metanol } \\
\text { Daun Gude }\end{array}$ & 5-Fluoro uracil \\
\hline $500 \mathrm{ug} / \mathrm{ml}$ & 6,7 & 63,4 \\
$400 \mathrm{ug} / \mathrm{ml}$ & 32,7 & 81,7 \\
$300 \mathrm{ug} / \mathrm{ml}$ & 78,6 & 82,8 \\
$200 \mathrm{ug} / \mathrm{ml}$ & 96,5 & 84,1 \\
$100 \mathrm{ug} / \mathrm{ml}$ & 97,5 & 93,0 \\
\hline
\end{tabular}

Sumber: Data Primer

Dari data tersebut kemudian dihitung $\mathbf{I C}_{50}$ dengan cara interpolasi regresi linier, didapatkan hasil sebagai berikut:

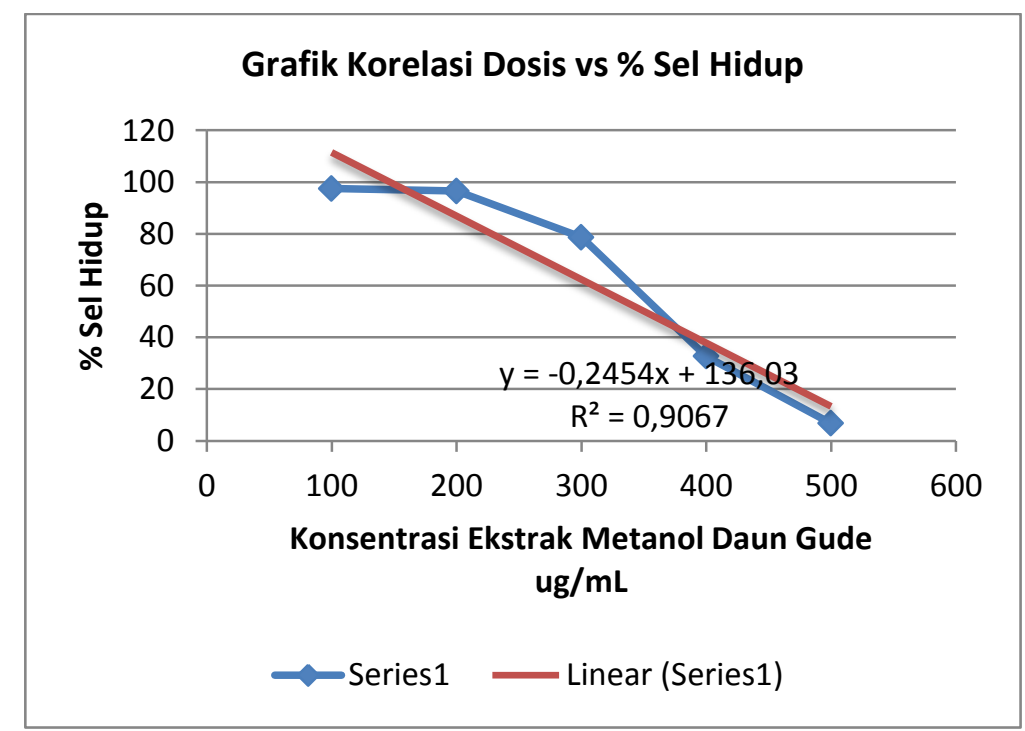




\section{JURNAL TEKNOLOGI LABORATORIUM}

(www.teknolabjournal.com)

Vol.6, No.1, Maret 2017, pp. $31 \sim 38$

ISSN: 2338 - 5634 (print); ISSN: 2580-0191 (online)

Received : 23-03-2017; Revised : 25-04-2017 ; Accepted : 23-05-2017

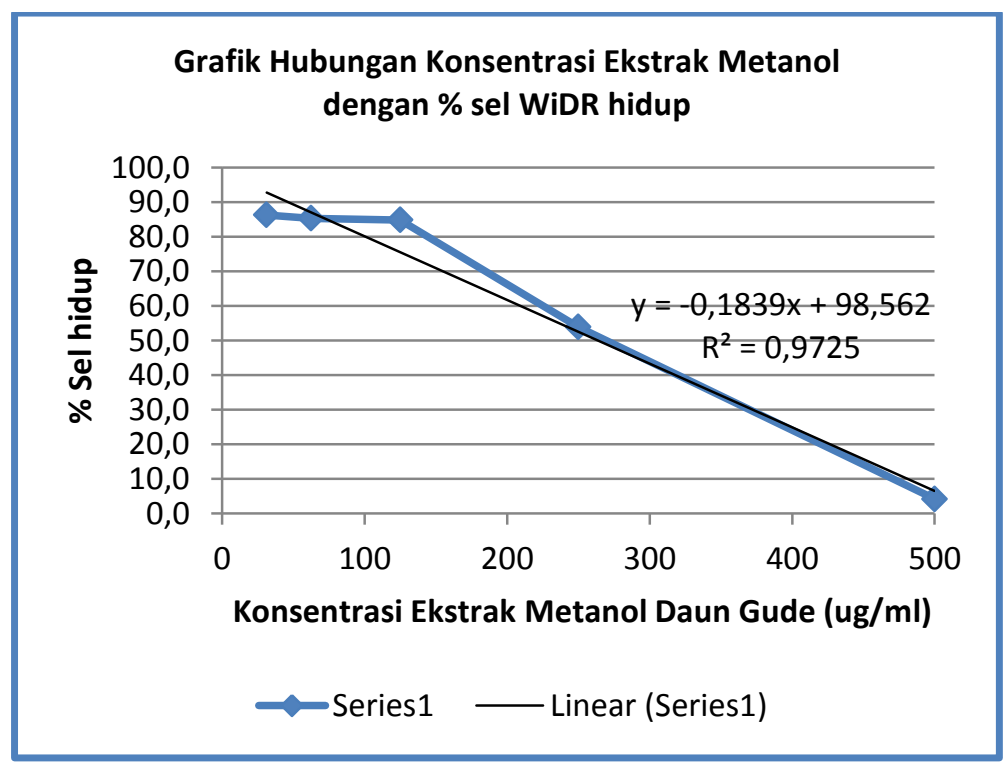

Sumber: Data Primer

Gambar 1. Hubungan Konsentrasi Ekstrak Metanol Daun Gude dengan \% Sel WiDr Hidup

Dari grafik tersebut didapatkan nilai $\mathrm{IC}_{50}$ ekstrak metanol daun gude terhadap sel kanker kolon type WiDr sebesar $307 \mu \mathrm{g} / \mathrm{ml}$

Gambaran mikroskopis sel WiDr ditunjukkan dalam gambar berikut:

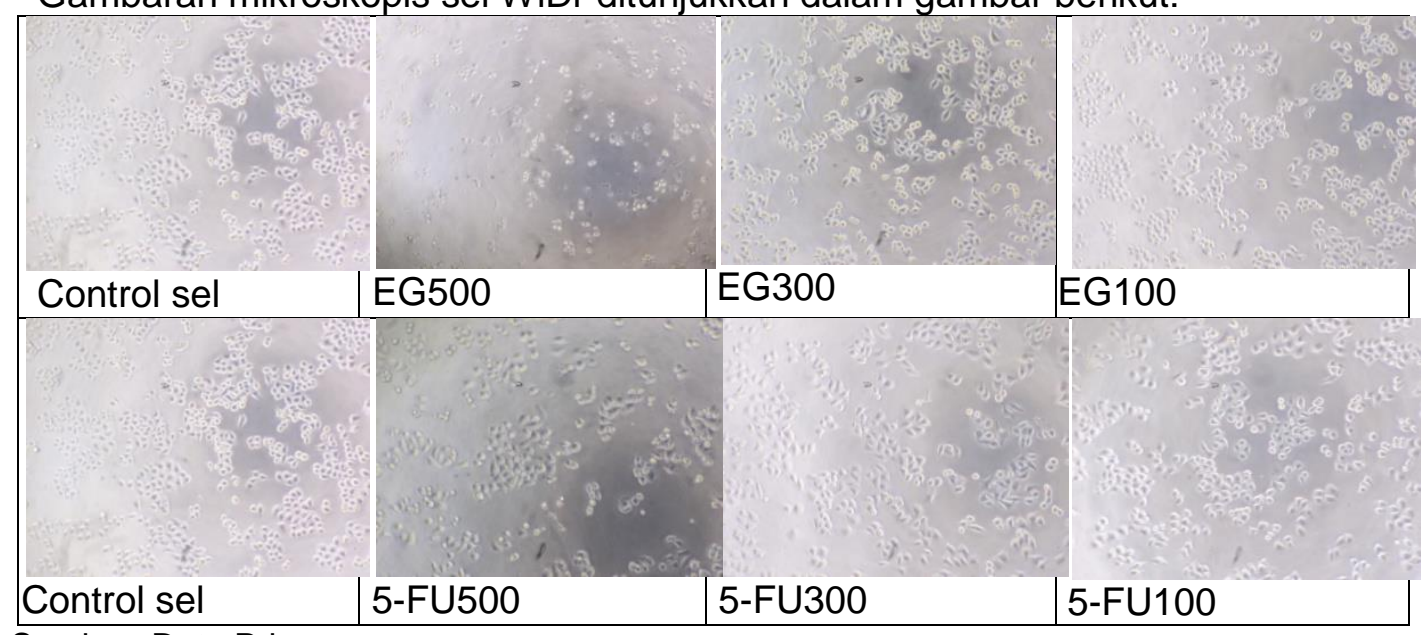

Sumber: Data Primer

Gambar 2. Gambaran Mikroskopis Sel WiDr setelah Perlakuan dengan Ekstrak Metanol Daun Gude

\section{Keterangan:}

EG500; EG300; EG100 = Sel dengan perlakuan ekstrak metanol daun gude $500 \mu \mathrm{g} / \mathrm{ml}$, $300 \mu \mathrm{g} / \mathrm{ml}$ dan $100 \mu \mathrm{g} / \mathrm{ml}$; 5FU500; 5FU300; 5FU100 = Sel dengan perlakuan 5 Fluorouracil $500 \mu \mathrm{g} / \mathrm{ml}, 300 \mu \mathrm{g} / \mathrm{ml}$ dan $100 \mu \mathrm{g} / \mathrm{ml}$ 


\section{JURNAL TEKNOLOGI LABORATORIUM}

(www.teknolabjournal.com)

Vol.6, No.1, Maret 2017, pp. $31 \sim 38$

ISSN: 2338 - 5634 (print); ISSN: 2580-0191 (online)

Received : 23-03-2017; Revised : 25-04-2017 ; Accepted : 23-05-2017

Flavonoid yang terkandung dalam daun gude antara lain sub golongan flavon terdiri dari apigenin, vitenxin, isovitexin, luteolin dan orientin. Flavonoid sub golongan isoflavon terdiri dari biochanin A dan formononentin. Sub golongan flavanol terdiri dari quercetin dan isorhamnetin. Sub golongan flavanon terdiri dari naringenin dan pinostrobin. Sub golongan isoflavanon adalah cajanol sedangkan sub golongan chalcon adalah pinostrobin-chalcon.[4]

Mekanisme flavonoid menghambat atau mematikan sel kanker dapat terjadi melalui berbagai cara yaitu: 1) sebagai antioksidan dengan cara menginaktivasi radikal oksigen, 2) berikatan dengan senyawa elektrofilik, 3) menginduksi enzim protektif aktivitas konjugasi, 4) meningkatkan kecepatan apoptosis, 5) menghambat proliferasi sel, 6) menghambat peroksidasi lipid, 7) menghambat angiogenesis, 8) donasi hydrogen, dan 9) menghambat oksidasi DNA.[6]

Beberapa penelitian yang telah dilakukan antara lain oleh Wenzel et al. (2005) telah menemukan bahwa flavon meningkatkan up take piruvat atau laktat oleh mitokondria akibatnya meningkatkan produksi radikal superoksida dan memicu apoptosis sel kanker kolon HT-29. Flavonoid sub golongan flavon lain yang terkandung dalam daun gude seperti luteolin dan apigenin teridentifikasi menghambat efek enzim sitokrom CYP1A akibatnya menginduksi apoptosis.[7] Sedangkan dari sub golongan flavonol yaitu quercetin, selain teridentifikasi menghambat efek enzim sitokrom CYP1A juga meningkatkan kadar p53 yang akibatnya terjadi induksi apoptosis. Selain itu quercetin juga menginduksi conjugating enzyme fase II sehingga mencegah deplesi glutathione tereduksi (GSH) yang diduga kuat sebagai mekanisme potensial mencegah perkembangan tumor [7]. Aktivasi apoptosis merupakan karakteristik quercetin.[8] Lim et al. (2007) juga melaporkan bahwa luteolin menyebabkan siklus sel terhenti pada fase G2/M melalui penurunan ekspresi cyclin B1 dan pembelahan sel dan apoptosis pada sel kanker kolon HT-29.[9]

Pengujian dilanjutkan dengan uji flowcytometry untuk mengetahui kematian sel kanker WiDr yang diberi perlakuan ekstrak methanol daun gude melalui proses apoptosis atau nekrosis. Uji flowcytometry dengan konsentrasi $1 / 2 \times \mathrm{IC}_{50}$ diperoleh hasil sebagai berikut: 


\section{JURNAL TEKNOLOGI LABORATORIUM}

(www.teknolabjournal.com)

Vol.6, No.1, Maret 2017, pp. $31 \sim 38$

ISSN: 2338 - 5634 (print); ISSN: 2580-0191 (online)

Received : 23-03-2017; Revised : 25-04-2017 ; Accepted : 23-05-2017
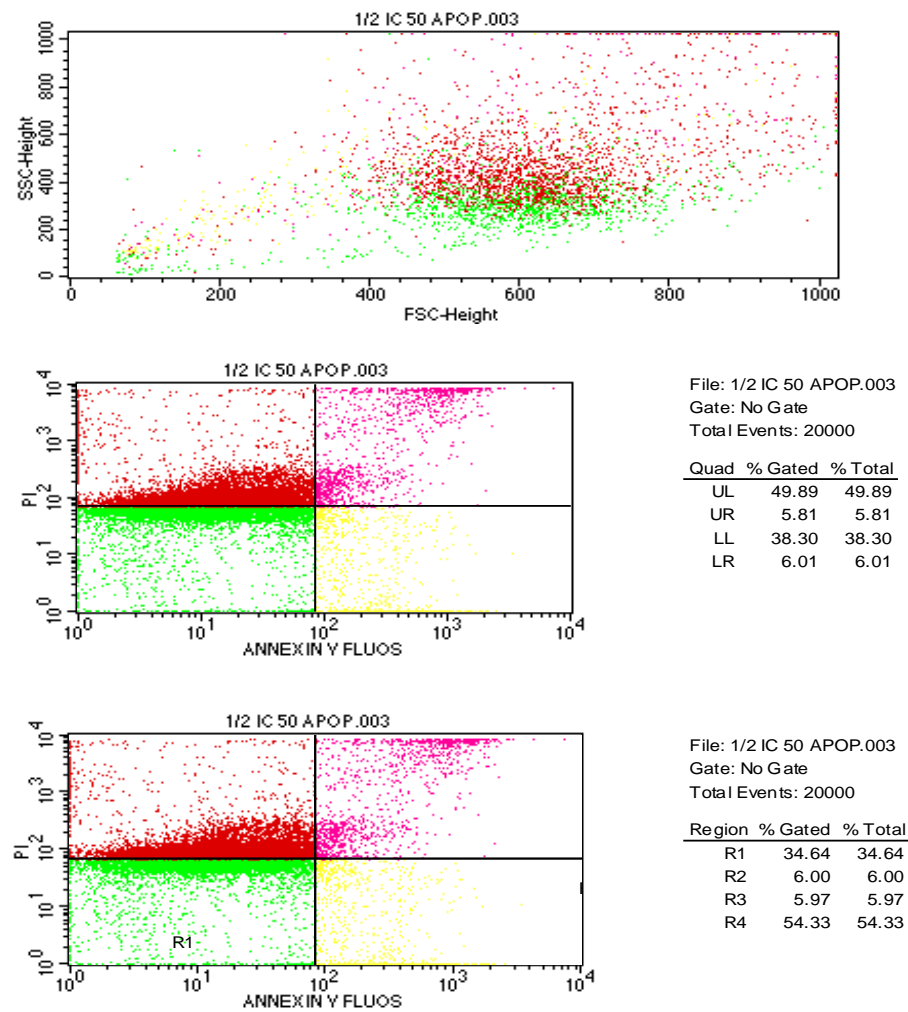

File: $1 / 2$ IC 50 APOP. 003
Gate: No Gate
Total Events: 20000
Region $\%$ Gated
\begin{tabular}{crr} 
Re & Total \\
\hline R1 & 34.64 & 34.64 \\
R2 & 6.00 & 6.00 \\
R3 & 5.97 & 5.97 \\
R4 & 54.33 & 54.33
\end{tabular}

Gambar 3. Hasil Uji Flocytometry $1 / 2$ x IC $5_{50}$ Ekstrak Metanol Daun Gude

Uji flowcytometry dapat membedakan sel yang apoptosis atau nekrosis, didasarkan pada kemampuan Annexin $\mathrm{V}$ suatu anggota annexin intraseluler yang berikatan dengan phosphatydilserin yang tergantung ion $\mathrm{Ca}^{2+}$. Pada kondisi normal fosfatidilserin hanya terdapat pada lapisan intraseluler pada membran plasma sel sehat. Jika terjadi awal apoptosis membrane asimetri hilang dan fosfatidilserin mengalami translokasi ke lapisan eksternal membrane sel. Annexin $\mathrm{V}$ yang dilabel fluorochrom digunakan mendeteksi target ini. Annexin $\mathrm{V}$ tidak bisa membedakan antara sel yang apoptosis dan nekrosis, untuk membantu membedakannya digunakan Propidium lodide (PI). Fase awal apoptosis sel tidak bereaksi dengan PI, sedangkan pada apoptosis fase akhir sel akan terwarnai oleh PI, karena pewarna ini akan menembus nucleus dan berikatan dengan DNA. Propidium iodide adalah pewarna fluoresen yang berikatan dengan DNA, jika tereksitasi pada panjang gelombang 488 $\mathrm{nm}$ sinar laser, akan dapat terdeteksi yang digunakan untuk mengevaluasi sel yang masih hidup atau sel yang masih mengandung DNA dalam siklus sel yang dianalisis secara flowcytometry.

Hasil uji flowcytometry sel WiDr dengan perlakuan ekstrak methanol daun gude dosis $1 / 2 \mathrm{IC}_{50}$ menunjukkan $49,98-54,33 \%$ sel berada pada $\mathrm{R} 4$ hal ini menunjukkan sel sudah mengalami apoptosis akhir atau sudah nekrosis. Hanya 6\% terdeteksi sel tahap awal apoptosis, $6 \%$ sudah masuk fase apoptosis. Sedangkan dengan dosis ekstrak methanol daun gude $1 \times I C_{50}$ menunjukkan $74 \%$ sel sudah mengalami nekrosis, $13,7 \%$ mengalami apoptosis, dan 4,3\% memasuki awal apoptosis dan tinggal 7,6\% sel yang hidup. Hal ini menunjukkan bahwa ekstrak methanol daun gude menyebabkan 


\author{
JURNAL TEKNOLOGI LABORATORIUM \\ (www.teknolabjournal.com) \\ Vol.6, No.1, Maret 2017, pp. $31 \sim 38$ \\ ISSN: 2338 - 5634 (print); ISSN: 2580-0191 (online)
}

Received : 23-03-2017; Revised : 25-04-2017 ; Accepted : 23-05-2017

nekrosis sel kenker kolon type WiDr. Nekrosis tersebut dapat diakibatkan juga oleh masa inkubasi yang lama (24 jam) sehingga fase apoptosis sudah terlewati. Hasil penelitian ini menggambarkan bahwa efek flavonoid yang terkandung dalam ekstrak methanol daun gude adalah melalui mekanisme mempercepat apoptosis.

\title{
4. Kesimpulan dan Saran
}

Ekstrak methanol daun gude mempunyai aktivitas antikanker terhadap sel kanker kolon type WiDr dengan pengujian secara in vitro, didapatkan $\mathrm{IC}_{50}$ sebesar $307 \mathrm{ug} / \mathrm{ml}$ dengan mekanisme nekrosis. Mengingat kandungan fenol total yang tinggi pada daun gude, maka penelitian dapat dilanjutkan menggunakan ekstrak dengan sub fraksi pelarut untuk menelusuri zat aktif yang mempunyai efek antikanker khususnya kanker kolorectal.

\section{Ucapan Terimakasih}

Terimakasih kami ucapkan kepada Direktur Poltekkes Kemenkes Yogyakarta, selaku penyandang dana, Kepala Laboratorium FKU UGM Yogyakarta beserta teknisi.

\section{Daftar Pustaka}

[1] C. Kanadaswami, L. T. Lee, P. P. H. Lee, J. J. Hwang, F. C. Ke, Y. T. Huang, and M. T. Lee, "The antitumor activities of flavonoids," In Vivo (Brooklyn)., vol. 19, no. 5, pp. 895-910, 2005.

[2] J. Ferlay, I. Soerjomataram, R. Dikshit, S. Eser, C. Mathers, M. Rebelo, D. M. Parkin, D. Forman, and F. Bray, "Cancer incidence and mortality worldwide: Sources , methods and major patterns in GLOBOCAN 2012," Int. J. Cancer, vol. 386, no. 136, pp. E358-E386, 2015.

[3] N. Loganayaki, P. Siddhuraju, and S. Manian, "A comparative study on in vitro antioxidant activity of the legumes Acacia auriculiformis and Acacia ferruginea with a conventional legume Cajanus cajan Estudio comparativo de la actividad antioxidante in vitro de las legumbres Acacia auriculiformis y Aca," CyTA J. Food, vol. 9 No. 1, no. December 2014, pp. 37-41, 2011.

[4] A. Nix, C. A. Paull, and M. Colgrave, "The flavonoid profile of pigeonpea, Cajanus cajan: a review," Springerplus, vol. 4, no. 1, p. 125, 2015.

[5] Aja, P.M., Alum, E.U., Ezeani, N. and N. Nwali, B.U., Edwin, "Comparative Phytochemical Composition of Cajanus cajan Leaf and Seed," Intl. J. Microbiol. Res., vol. 6, no. 1, pp. 42-46, 2015.

[6] J. Y. Chahar MK, Sharma N, Dobhal MP, "Flavonoids: A versatile source of anticancer drugs.," Pharmacogn. Rev., vol. 5, no. 9, pp. 1-12, 2011.

[7] S. Ramos, "Review Cancer chemoprevention and chemotherapy: Dietary polyphenols and signalling pathways," Mol Nutr Food Res, vol. 52, pp. 507-526, 2008. 


\section{JURNAL TEKNOLOGI LABORATORIUM}

(www.teknolabjournal.com)

Vol.6, No.1, Maret 2017, pp. $31 \sim 38$

ISSN: 2338 - 5634 (print); ISSN: 2580-0191 (online)

Received : 23-03-2017; Revised : 25-04-2017 ; Accepted : 23-05-2017

[8] D. I. Hertzog and O. S. Tica, "Review Molecular mechanisms underlying the anticancerous action of flavonoids," Curr. Heal. Sci. J., vol. 38, no. 4, pp. 145-149, 2012.

[9] S. Lim, J. Xu, J. Kim, T. Chen, X. Su, J. Standard, and W. Wang, "Role of Anthocyanin-enriched Purple-fleshed Sweet Pottao P40 in Colorectal Cancer Prevention," Mol Nutr Food Res, vol. 57, no. 11, pp. 1908-1917, 2013.

[10] International Agency for Research in Cancer, 2012. GLOBOCAN: Estimated Cancer Incidence, Mortality and Prevalence Worldwide in 2012, WHO. 